Please do not remove this page

RMIT

UNIVERSITY

\title{
Work integrated learning and the humanities: Possibilities and future directions
}

Pocknee, C; Pretto, Gabriella

https://researchrepository.rmit.edu.au/esploro/outputs/9921858633201341/filesAndLinks?institution=61RMIT_INST\&index=null

Pocknee, C., \& Pretto, G. (2012). Work integrated learning and the humanities: Possibilities and future directions. International Journal of the Humanities, 9(10), 175-188.

https://researchrepository.rmit.edu.au/discovery/fulldisplay/alma9921858633201341/61RMIT_INST:Resea rchRepository

Document Version: Published Version

Repository homepage: https://researchrepository.rmit.edu.au

(c) Common Ground, Catherine Pocknee, Gabriella Pretto.

Downloaded On 2023/04/27 01:12:23 +1000 
Thank you for downloading this document from the RMIT Research Repository.

The RMIT Research Repository is an open access database showcasing the research outputs of RMIT University researchers.

RMIT Research Repository: http://researchbank.rmit.edu.au/

\section{Citation:}

Pocknee, C and Pretto, G 2012, 'Work Integrated Learning and the Humanities: Possibilities and future directions', International Journal of the Humanities, vol. 9, no. 10, pp. 175-188.

See this record in the RMIT Research Repository at:

http://researchbank.rmit.edu.au/view/rmit:18002

Version: Published Version

Copyright Statement: (c) Common Ground, Catherine Pocknee, Gabriella Pretto

Link to Published Version:

http://ijh.cgpublisher.com/product/pub.26/prod.2231 


\title{
Work Integrated Learning and the Humanities: Possibilities and Future Directions
}

\author{
Catherine Pocknee, Swinburne University of Technology, Victoria, \\ Australia \\ Gabriella Pretto, RMIT University, Victoria, Australia
}

\begin{abstract}
In 2008, in response to government, industry and community demand, Australia completed its first large scale scoping study of Work Integrated Learning (WIL) curriculum in contemporary Australian higher education. The aim of the WIL project was to document and scope current WIL practices nationally, and identify ways to improve the educational experience of students, in order to produce more industry focused, work ready graduates (Patrick et al., 2008). The project, which was government funded and included 37 of Australia's 39 universities, found that all of those who participated in the study saw real value in adopting a more industry focused curricula, however, it also revealed that many were still grappling with selecting from the range of options available, and finding the most appropriate way of integrating them into courses. Traditional disciplines such as nursing, medicine, education and engineering have always had an embedded work integrated learning component in their curriculum, usually in the form of industry placements, but many disciplines, in non-traditional areas such as the liberal arts, were new to this concept of WIL and unsure of how to customise programs to meet the needs of their particular discipline. To address this issue, a series of narratives or vignettes were developed and compiled to provide insight into not only to the diverse range of pedagogical practices in the area, but also offer practical advice on how to establish, develop and manage programs in an innovative and sustainable way. This paper analyses more closely the Australian research on embedding WIL in non-traditional areas and highlights a number of key vignettes that offer significant insights into possible future directions for the Humanities as they come to terms with this challenge.
\end{abstract}

Keywords: Work Integrated Learning (WIL), Vignettes, Professional Practice

\section{Introduction}

$\mathrm{T}$

HERE HAS LONG been a global trend in Higher Education to link the role of universities to economic growth and the enhancement of employability outcomes for students (Ball, 2003; Beckmann, Cooper, \& Hill, 2009; Marginson, 2002) Policy surrounding notions of 'new public management', market forces, and accountability have long dominated the UK, Europe and North America, and have forced not only individual academics, but whole institutions, to reviewing their teaching practices (Becher \& Trowler, 2001). Australia has not been immune to these global trends and despite the recent Global Financial Crisis (GFC) Australian Universities are still under pressure to produce 'work ready' graduates to meet skill shortages in an economy responding to a resources boom.

In 2008, in response to government, industry and community demand, Australia completed its first large scale scoping study of Work Integrated Learning (WIL) curriculum in contemporary Australian higher education. The aim of the WIL project was to document and scope current WIL practices nationally, and identify ways to improve the educational experience 
of students, in order to produce more industry focused, work ready graduates (Patrick, et al., 2009).

The project, which was nationally funded and included 37 of Australia's 39 universities, found that all of those who participated in the study saw real value in adopting a more industry focused curricula, however, it also revealed that many were still grappling with terminology, defining the concept within the perspective of their disciplines, and finding the most the appropriate way of integrating programs into courses. Traditional disciplines such as nursing, medicine, education and engineering have always embedded a work integrated learning component into their curriculum, usually in the form of industry placements, but many disciplines, in non-vocational areas such as the liberal arts, were new to the concept of WIL and unsure of how to customise their programs to meet the needs of a particular discipline.

To address this issue, a series of narratives or vignettes were developed and compiled which gave insight into not only to the diverse range of pedagogical practices in the area, but also provided practical advice on how other universities established, developed and managed WIL programs in an innovative and sustainable way. In 2009, these vignettes were published on the Australian Collaborative Education Network (ACEN) website for broader dissemination: http://www.acen.edu.au/vignettes. Since that time, the number of vignettes has grown, with many more now specifically addressing the field of Humanities.

This paper analyses more closely the Australian research on embedding WIL in non-traditional areas and highlights a number of key concepts gathered from practitioner vignettes that offer significant insights into possible future directions for the Humanities as they come to terms with this challenge.

\section{Methodology}

While the larger national scoping study adopted a participatory action research methodology (Costello, 2003; Jones, 2006; Whitehead \& McNiff, 2006), it was decided that a narrative based, case study approach (Merriam, 1998; Stake, 2005; Yin, 2003) would be more appropriate for the vignette component of the research as the research team was keen to explore a variety of WIL experiences in depth to give voice to the subtleties and complexities of each context and provide participants with tangible models on which to base their future work. Over the period of the project the vignettes became a bricolage of stories across multiuniversities and multi-disciplines, some nested (Denzin \& Lincoln, 2005) within individual universities and others within particular disciplines.

Vignette participants were purposefully recruited from presenters at state-based symposia, meetings and conferences organised by the research team members, and through contacts within the Australian Collaborative Education Network (ACEN) and partner universities.

Vignette data was collected via a standardised template. The template was designed to collect information about programs such as discipline, employment sector, assessment, credit, student payment and whether the program was a compulsory part of a course or an optional component. In addition, academics were asked to provide an overview, outline the structure of the program, and identify special features as well as future work/improvements.

Vignettes were posted in an open, online environment as authentic examples of current practice; they were not selected, evaluated, categorized or summarised. It was hoped that minimal editing would provide a human face for a particular WIL experience and allowing 'real people' to explain in their own words, their version, spoken in their own words (Den- 
scombe, 2007), why their programs ran the way they did. This element of narrative inquiry (Clandinin, 2007; Clough, 2002; Elliott, 2005) is a popular tool of educational research and underpinned the case study vignettes as "an opportunity for teachers to tell their stories of practice, and then to build from that telling, various opportunities for reflection and learning" (Lyons \& LaBoskey, 2002, p. 61)

\section{Australian WIL Models}

The Australian study identified over 47 different terms to describe WIL (Table1), with the most common being traditional terms such as; work placement, practicum, internship, cooperative education, fieldwork, industry-based learning or clinical practice (Patrick, et al., 2009 p. 9). 
Table 1: WIL Terminology and Frequency of Use

\begin{tabular}{|c|c|c|c|}
\hline Rank & Term/s (Frequency*) & Rank & Term/s (Frequency*) \\
\hline 1 & Practicum (35) & 13 & Work Experience (3) \\
\hline 2 & Professional Practice (32) & 14 & $\begin{array}{l}\text { Clinical Practice, Clinical education, } \\
\text { Doctoral Supervision with Industry Partners } \\
\text { Work Based Learning (2) }\end{array}$ \\
\hline 3 & $\begin{array}{l}\text { Internship, Workplace Learn- } \\
\text { ing, } \\
\text { Work Integrated Learning (31) } \\
\end{array}$ & & \multirow{10}{*}{$\begin{array}{l}\text { Academic Service Learning, Adult Learn- } \\
\text { ing, Androgogy, Clinical Attachments, } \\
\text { Clinical Experience, Competency assess- } \\
\text { ment, } \\
\text { Corporate Business Management, } \\
\text { Employment Experience, } \\
\text { Engaged Learning, Experiential placements, } \\
\text { Faculty Internships, Field Placements, } \\
\text { Industrial Experience, Industry experience, } \\
\text { Industry links, Industry Placement, } \\
\text { Learning in the Workplace, } \\
\text { Operational Performance, Practical Projects, } \\
\text { Practical Training, Practice Based Educa- } \\
\text { tion, Practice-based learning, } \\
\text { Problem-based learning, } \\
\text { Professional experience, } \\
\text { Professional Learning, Sandwich, Site visits } \\
\text { Structured workplace learning, } \\
\text { Student employability, Volunteering (1) }\end{array}$} \\
\hline 4 & Industry-based Learning (25) & & \\
\hline 5 & Project-based Learning (24) & & \\
\hline 6 & $\begin{array}{l}\text { Cooperative Education, Field- } \\
\text { work Education }(20)\end{array}$ & & \\
\hline 7 & Service Learning (12) & & \\
\hline 8 & Real World Learning (9) & & \\
\hline 9 & $\begin{array}{l}\text { University Engaged Learning } \\
(7)\end{array}$ & & \\
\hline 10 & Placements (6) & & \\
\hline 11 & Experiential learning, (5) & & \\
\hline 12 & $\begin{array}{l}\text { Clinical Placements, } \\
\text { Professional Placement (4) }\end{array}$ & & \\
\hline
\end{tabular}

Often a variety of terms were used within a specific university in response to discipline needs, administrative expediency or simply for marketing purposes. One university described its WIL activities in terms of 'Community Engagement' and its ability to customise its curriculum to meet its social and community needs. In addition to these institutional definitions, academics tended to adopt theoretical and/or practical definitions of WIL to reflect the broad nature of WIL and identify the different emphases placed on it by both the individual and 
the institution. For example, WlL can be used to describe curriculum integration, engagement with industry, real-life experience, integration of theory and practice, volunteering, community engagement or various combinations of all. Nonetheless, whatever terminology is used, academics have agreed on the importance of ensuring that students have a shared understanding of the objectives and expectations for WIL.

Consequently, the national study decided that 'work integrated learning' (WIL) was a useful and practical way of describing a range of approaches and strategies that integrate theory with the practice of work within a purposefully designed curriculum (Patrick, et al., 2009).

\section{Emerging Practice}

The aim of the vignettes was to connect and inform participants of current practice across the disciplines and across the sector. It was here, in this shared community of practice that the participant's response was at its most vibrant and innovative. The vignettes clearly identified a rapid growth in the range of WIL learning experiences that were more embedded within the university learning context rather than in the traditional workplace context.

From early in the project it became clear that participants were interested and enthusiastic about sharing practice with others. Vignettes or practitioner stories became crucial to understanding how others in different disciplines, and even within the same discipline, had developed models to suit their unique context. In an attempt to let a diversity of 'voices' be heard, it was decided that the project would collect and disseminate a wide variety of WIL affordances. Participants could provide vignettes or stories about cross-university programs, faculty based initiatives, discipline specific examples, strategies for optimising workplace learning, technology innovation or even examples of resource development. In the early stage of the project most vignettes were submitted by WIL co-ordinators and tended to represent variations on traditional placement programs, however as the project progressed more innovative examples began to be submitted; virtual companies, design studios, workplace projects and consultancies.

Vignettes proved to be a genuine and authentic voice for academics, not only for those who worked directly within WIL programs, but also for those who were responsible for visiting students in workplaces, liaising with industry supervisors or developing resources, reviewing and redesigning curriculum. Many of the vignettes were based on the well established traditions of the 'sandwich year' or 'placement' programs, but on closer inspection the researchers were able to identify more embedded, sophisticated strategies for dealing with factors such as urban or rural location, student ethnicity, discipline values, community needs as well as the individual 'mission' of universities.

As part of the project a series of vignettes were published on the Australian Learning and Teaching Council (ALTC) and ACEN websites, and since the completion of the WIL project a significant number of vignettes have been submitted to ACEN for future publication. It was only after the vignettes began to be published and disseminated that the enormous range of models and the complexity and richness they demonstrated became obvious. Many of these vignette's featured WIL examples from areas not normally mentioned in literature and it was not just a case of 'one size, fits all'; what was revealed was a variety of complex models finely nuanced in local contexts and conditions such as the 'Maths in Motion Program' (Hemphill, 2009) where biomechanics students would work with secondary school students 
in teams of 3 or 4 in a reciprocal arrangement, Certificate II Hospitality students who participated in the school canteen program for 6 months paid by the local council (Newell, 2009) or occupational therapy students who were placed in hospitals in China, India, South Africa and the Ukraine for 7 weeks (Goddard \& Gribble, 2008). In addition, there were vignettes that incorporated technology into WIL programs such as the law virtual placement project and on-line authentic patient scenarios for nursing, paramedic and podiatry (Shirley, Davies \& Cockburn, 2008).

\section{Extending Existing WIL Models}

Over the years much work has been done to identify the range of work-based learning programs currently being used across the sector. Freestone, Thompson and Williams' (2006) research was comprehensive and identified and categorised a wide range of work-based learning models which ranged from brief work place visits to more formalised forms of learning contexts such as co-operative programs, apprenticeships and traineeships. Their work identified some more unusual formats such as joint industry-university partnerships, employment-based learning and post-course internships. In Australia, this rapid growth of embedded WIL models seems to be aligned to a number of national policy initiatives such as the push to incorporate graduate attributes and employability skills into curriculum, the increased vocationalisation and marketisation of university courses, as well as the internationalisation of curriculum (Barrie, Hughes, \& Smith, 2009).

These existing models, together with the various forms of WIL identified via the project vignettes, offer significant insight into the curriculum options which could be adopted or utilized by the Humanities in the future. In an attempt to articulate the current range of WIL models now emerging and their unique learning context, the authors have developed visual schema which is based on the work of Freestone, Thompson and Williams' (2006). This schema (ref Figure 1.) not only identifies and extends the range of models available to practitioners, but also identifies the WIL setting in which they are currently being used and acknowledges the complex relationships that need to be established when considering which options are most suitable for a particular discipline. The schema identifies potential WIL settings where the Humanities are likely to find future sustainable options. 


\section{Work Integrated Learning Models}

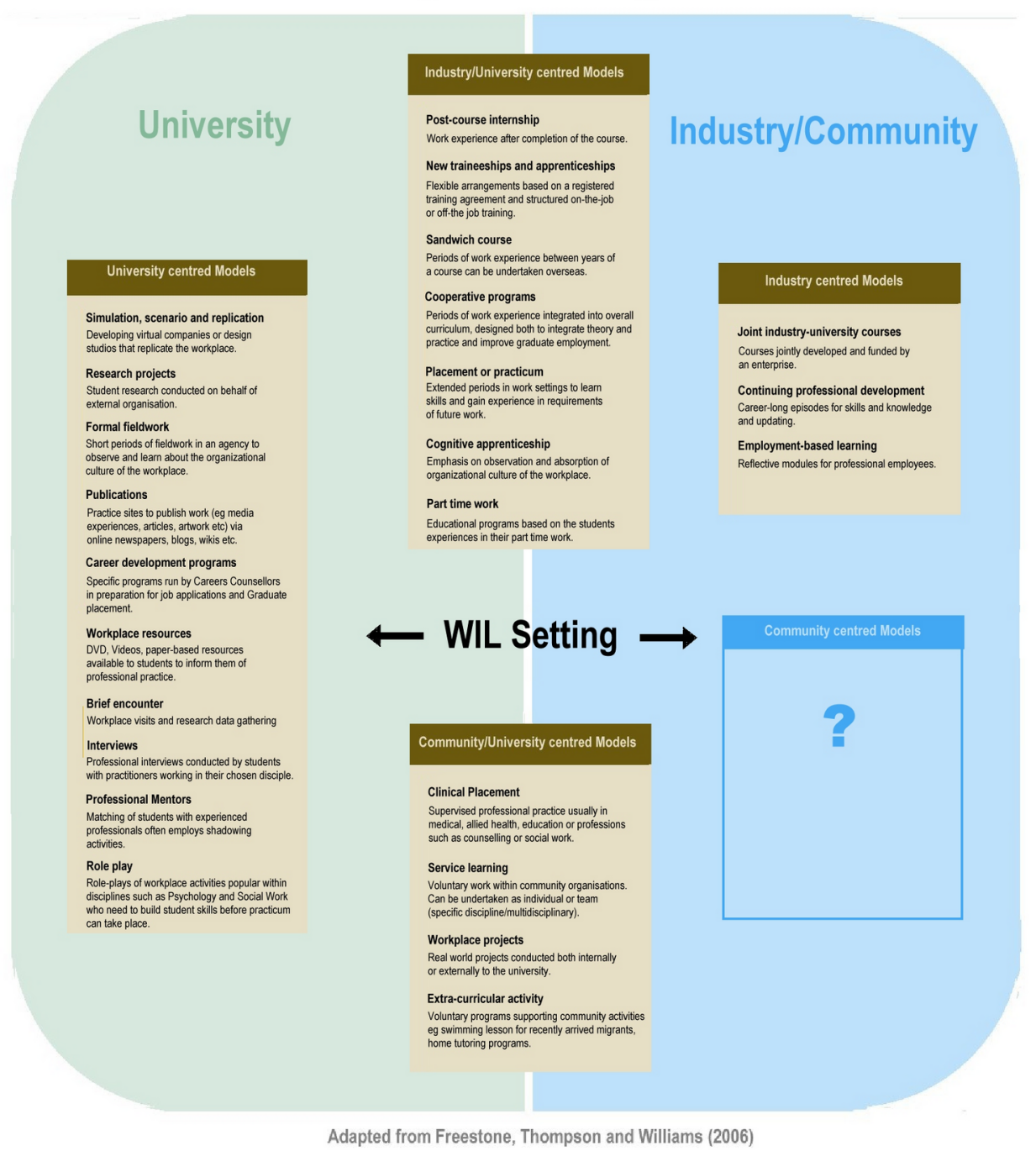

Figure 1: Work Integrated Learning Models

This schema attempts to include the rapidly increasing range of university based learning WIL activities such as workplace projects, role plays, service learning and volunteer activities which are often called up as 'embedded WIL initiatives' by universities, particularly by those who had undergone extensive curriculum renewal in the area. The national project identified universities who had undertaken curriculum renewal, most of whom had developed a much broader range of programs both internal and external to the university setting and were also more likely to have adopted initiatives that prepared students for an external program experience. WIL curriculum in these universities was seen as a continuum of learning experiences over the life of a course. The schema also attempts to reflect the greater role 
taken by Careers Units in programs, as well as the increasing importance of professional mentors and part-time work in shaping student perceptions and capabilities.

It also became evident that the 'workplace learning affordances' (Billet, 2001 p. 209) were increased for students when the university was able to tap into a variety of sophisticated relationships with both their community partners as well as industry partners. This was particularly evident the Paramedic Degree Program (Brightwell, 2008), Local Government Park and Recreation Program (Dressier, 2009) and the community based consultative project by Garo Derounian (2008). Again the breadth and variety of WIL learning experiences were increased when responsibility for the learning was a mutual one, rather than dominated by either the university or industry. However, it must be noted that the student WIL experience is still predominantly university centred with very few industry or community centred options. This is an area that Humanities may need to explore further, particularly via their existing community based relationships if they wish to carve out unique discipline specific experiences.

The project also found the location of the learning doesn't necessarily limit the quality of the learning experience, as simulation, virtual laboratories and authentic workplace projects are rapidly emerging as viable options. Pragmatically, these types of WIL learning experiences are easier to include within courses; they also expose students to a range of new technologies as they have an impact on the field; and often relieve the pressure of recruiting sufficient workplaces to support individual programs. While many of these types of educative practices have always been contained within Humanities curricula, they are only now beginning to be given recognition and prominence as discipline specific 'professional practice'.

\section{Challenges for the Humanities}

Defining the Humanities is a difficult and ongoing challenge for educators. Traditionally, in Australia, the Humanities have been known as the liberal arts, and have incorporated disciplines such as English, linguistics, history, modern foreign languages, classical studies, music, philosophy, theology, archaeology, political science and sociology (Sandringham Publishing, 2009). Teaching in the Humanities was about imparting general knowledge and developing rational thought processes and intellectual capabilities and skills. Educationally the Humanities has always held a position in contrast to the more professional or vocational courses such as law, medicine, accounting or education, however, times are changing and new paradigms are emerging.

Most Australian universities are now including a much broader range of subjects than those more traditionally identified with the 'Humanities' often in response to the increased rationalisation of course offerings and a push for increased vocational outcomes. For instance, subjects such as journalism, creative writing, media communication, interactive games development, event management, film and television have been added. In the past, access to these disciplines was through highly sought after cadetships or learning on the job programs, whereas now many universities offer them as full courses or as majors within Arts degrees in response to a growing demand for work-integrated learning arrangements (WIL) across Australian higher education (Billett 2009).

This trend has put extra pressure on academics to embed authentic WIL practices that are not only flexible enough to accommodate a rapidly changing student demographic but also to meet a diversity of vocational outcomes. As Forde \& Meadows' vignette states “.... a student who has good general knowledge will work better in a newsroom, than one who has 
a specific interest (e.g. music) who may be better placed in a magazine." The advantage of this situation is that skills that are traditionally associated with the Humanities such as 'critical thinking' are now considered essential to all graduate learning and are often identified in university nominated employability and graduate attributes, and are subsequently embedded in other discipline content as well as 'vocational' programs. Pragmatically speaking this has made it harder for Humanities to lay claim to these skills as their own preserve.

Not only do Australian universities now offer a broader range of subjects under the $\mathrm{Hu}-$ manities banner many have recently realigned or rationalised their curriculum offerings and moved subjects from their traditional discipline homes to incorporate them in mega faculties for ease of administration. For example, some faculties in the study have seen subjects such as languages shifted to the Business Faculty so they can be more closely aligned with international trade, while Media and Communication were just as likely to be found within the Faculty of Design as the Faculty of Social Sciences. Traditional discipline barriers seem to have broken down, and new paradigms are emerging (Pomeranz, 2008). It will be important in the future for all disciplines who perceive themselves to be part of the 'Humanities' to build a collective identity and a collective voice. In Australia this collective identity is likely to be facilitated by professional bodies such as Deans of Arts, Social Sciences and Humanities (DASSH) as these bodies are already being targeted by Government policy implementers as the bodies responsible for discipline standards, educational leadership, consultation and professional development.

Challenging traditions and embedding new educational practice within a discipline area is a complex, difficult and challenging one; particularly when traditional discipline groups are disparately spread throughout the university. Collective identity can be worn down and the 'strategic relationships' (Patrick et al, 2009) so pivotal to presenting a coherent argument for adequate resources to fund new WIL initiatives can be severely compromised. The challenge for the Humanities in the future will be in identifying the professional bodies that are representative of all the disciplines involved in the Humanities, and then setting up workable structures to use those organisations to build a collective and meaningful voice. In practice this will mean greater engagement with, and perhaps even leading, the debate into the relationship between economic capital, social capital and educative role of the $\mathrm{Hu}-$ manities in undergraduate education.

These professional bodies will also need to play a greater role in the development of educational scholarship within the area. Significant research needs to be undertaken into identifying the effectiveness of Humanities undergraduate education and its future connection to curriculum development. There will be an increasing pressure in the future to show vocational relevance in an increasingly performative environment within higher education. From a WIL perspective there is also an urgent need to undertake research into the graduate employment destinations of Humanities graduates to identify where they find employment and how their educational experience has supported or influenced their choice of employment.

Applied research will also need to be undertaken into the identification of suitable WIL experiences for the Humanities students. It will not be enough to simply mimic traditional formats such as 'practicum' found in medicine, education and nursing; or 'sandwich programs' found in engineering where there is a direct correlation between the profession and the work placement. Embedding of WIL experiences in the Humanities is a more complex endeavour because of the very nature of the liberal arts. For an Arts graduate with a major in philosophy, history, literature, or politics, there is no direct connection to a job or vocational outcome, 
rather they learn a broad range of skills that are flexible and diverse enough and enable them to find employment in a variety of different fields.

Choices will need to be made; as what may prove to be a relevant experience for a linguist may not be appropriate for a political speech writer. New unique opportunities must be identified. These opportunities may grow from a greater engagement with other discipline groups or even from adopting a multi disciplinary approach, where a sociology student is placed in the human resource department of an accounting firm, or a collective group of students with a diverse set of skills undertaking a multifaceted project for a community organisation such as the Salvation Army.

Whatever options are chosen adequate resource allocation underpins all successful programs. Appropriate resources in this instance is not simply sufficient funds to recruit and administer a program it also includes sufficient academic time to develop and trial appropriate WIL curriculum, as well as allows for academic supervision of students while they are learning in an industry or community setting. Special attention needs to be given to the quality of the learning experience as not all placements are equal-nor are all projects, fieldwork, interviews or guest presenters. Equity issues surrounding international students and students with a disability need to be considered, as do financial considerations for students from a low socio economic background. A placement, program or learning experience which limits part time work or includes significant travel costs, can preclude some students from participating.

It is most important to ensure a worthwhile WIL experience not only for students but for academics, community and industry partners as well, as this goes to the very heart of sustainability. There needs to be a shared vision or understanding among all concerned as to the length, purpose and role of the WIL learning experience-it needs to be designed, reviewed and agreed by all. Adequate supervision by the workplace supervisor can be just as important and appropriate as academic supervision. Tasks and duties need to be relevant, achievable and professionally appropriate; and students need to be adequately prepared to actively engage with the WIL experience. The length of the WIL experience is another important factor; some employers are happy to meet with students on periodic basis and the work to be done on-campus, others are only interested in a 6 to 12 month placement. The key success factor to a successful placement or experience for students is its relevance to the curriculum they are studying at university and its alignment to the professional practice of their chosen discipline.

\section{Strengths and Future Directions}

Preparing students appropriately for the vast array of WIL learning opportunities on offer will indeed be a challenging one for academics working in the Humanities. Pragmatic decisions will need to be made and applied research will need to be undertaken if appropriate choices and sustainable models are to be developed.

Nevertheless, the Humanities comes to this juncture with a strong history of providing quality professional learning opportunities for students, both internally and externally to the university setting. Service learning, internships, volunteering, fieldwork and investigative research, particularly in government and community settings, have long been established practice within the Humanities and the expertise and experience gained through the develop- 
ment and delivery of these formats will be invaluable in establishing a solid base for future work.

What the vignettes of practice in this research project demonstrate is the significant potential available to the Humanities to develop new forms of WIL learning, whether they be in establishing an after-school swim program for Sudanese students (Hemphill, 2009), investigating innocent people who have been wrongly accused (Weathered, 2009), building graduate attributes through extra-curricular activities (Muldoon, 2009), or providing the music industry with mentors for youth 'at risk' (Aronson \& Hutterer, 2009). The opportunities are endless but will also strongly challenge academic traditions surrounding teaching and learning practice, but as Rowland (2002) notes, the greatest opportunities can lie in the fracture lines of change.

\section{Conclusion}

Policy changes, growing demands from employers and students, technological innovations and rationalisation of curriculum have all led to a greater vocalisation of higher education and placed enormous pressure on academics striving for relevance in an increasingly neoliberal world, but opportunity is often born out of adversity and innovation out of the painful fracture lines caused by change. Opportunities abound for academics working in the Humanities at the current time. Creative pedagogical change is taking place, old paradigms are transforming, new models of WIL are emerging and innovative ways of integrating WIL into traditional curricula areas such as the Humanities offer academics new opportunities to show relevance and meaning.

The vignettes identified in the WIL Report (2009) are evidence of the broad range of WIL models currently operating right across Australia in a range of contexts and discipline areas, both urban and rural. However embedding new practice within a discipline area is not a simple and straight forward task; it is a complex, difficult and an evolving one. It is not enough to just simply mimic traditional formats such as 'practicum' found in medicine, education and nursing; or 'industry placements' found in engineering. New models need to be investigated and developed; models which reflect the strengths of the disciplines working within the Humanities; models which are an extension of their professional practice and optimise social engagement and research; models which strengthen citizenship and participation in the community. Many of these models already exist and are embedded in current practice, but are simply not couched in the language of managerialism and accountability. The authors throw down the gauntlet to academics working in the Humanities around the world; provide us with new vignettes, new stories, new practices. Let us learn from you. 


\section{References}

Aronson, G., \& Hutterer, A. (2009). Music mentoring project WIL Vignettes Retrieved May 11, 2011, from http://www.acen.edu.au/vignettes/Music-mentoring-project-.php

Ball, S. (2003). The teacher's soul and the terrors of performativity. Journal of Educational Policy, $18(2), 215-228$.

Barrie, S., Hughes, C., \& Smith, C. (2009). The national graduate attributes project: Integration and assessment of graduate attributes in curriculum. Sydney: The Australian Learning and Teaching Council.

Becher, T., \& Trowler, P. (2001). http://www.altcexchange.edu.au/system/files/Multidisciplinary Industry_Based_Learning_SU.pdf(2 ed.). Philadelphia, PA: The Society for Research into Higher Education \& Open University Press.

Beckmann, A., Cooper, C., \& Hill, D. (2009). Neoliberalization and managerialization of 'education' in England and Wales: A case for reconstructing education. The Journal for Critical Education Policy Studies 7(2), 310-345.

Billett, S. (2009). Demands for placements for work integrated intense higher education. Retrieved May 11, 2011, from http:/www.jcu.edu.au/teaching/public/groups/everyone/documents/ advice/jcuprd_052432.pdf

Billett, S. (2001). Learning through work: Workplace affordances and individual engagement. http://www.altcexchange.edu.au/system/files/Multidisciplinary_Industry_Based_ Learning_SU.pdf(5), 209-214.

Brightwell, R. (2008). Paramedic Degree Program. WIL Vignettes Retrieved May 11, 2011, from http://www.acen.edu.au/vignettes/Paramedic-Degree-Programs_-a-university-and-industrypartnership.php

Clandinin, D. J. (Ed.). (2007). Handbook of narrative inquiry-Mapping a methodology. London, UK: Sage Publications.

Clough, P. (2002). Narratives and Fictions in Educational Research (1 ${ }^{\text {st }}$ ed.). Philadephia: Open University Press.

Costello, P. J. M. (2003). Action research. London: Continuum.

Denscombe, M. (2007). The Good Research Guide. Maidenhead: Open University Press.

Denzin, N. K., \& Lincoln, Y. S. (2005). The SAGE handbook of qualitative research (3 ed.). Thousand Oaks, California: Sage.

Elliott, J. (2005). Using Narrative in Social Research: Qualitative and Quantitative Approaches London: Sage Publications.

Forde, S., \& Meadows, M. (2008). Journalism Internships. WIL Vignettes Retrieved May 10, 2011, from http://www.acen.edu.au/vignettes/Journalism-Internships.php

Freestone, R., Thompson, S., \& Williams, P. (2006). Student Experiences of Work-Based Learning in Planning Education. Journal of Planning Education and Research (236-249).

Garo Derounian, J. (2008). Study of Live Consultative and Deliberative projects. WIL Vignettes, from http://www.acen.edu.au/vignettes/Study-of-live-consultative-and-deliberative-projects.php

Goddard, T., \& Gribble, N. (2008). Occupational Therapy Abroad: International Interdisciplinary service learning clinical placements. WIL Vignettes Retrieved May 11, 2011, from http://www.acen.edu.au/vignettes/Occupational-Therapy-Abroad.php

Hemphill, D. (2009). Maths in Motion Program. WIL Vignettes Retrieved May 11, 2011, from http:/www.acen.edu.au/vignettes/Sudanese-Swim-Program.php

Hemphill, D. (2009). Sudanese Swim Program. WIL Vignettes Retrieved May 11, 2011, from http://www.acen.edu.au/vignettes/Sudanese-Swim-Program.php

Jones, G. (2006). Other research methods. In M. Walter (Ed.), Social Research Methods an Australian Perspective (pp. 309, 318-321). South Melbourne, Australia: Oxford University Press.

Lyons, N., \& LaBoskey, V. K. (Eds.). (2002). Narrative inquiry in practice: advancing the knowledge of teaching. New York, NY: Teachers' College Press, Columbia University. 
Marginson, S. (2002). Nation-building universities in a global environment: The case of Australia. Higher Education, 43, 409-428.

McLennan, B., \& Keating, S. (2008). Work-Integrated Learning (WIL) in Australian Universities: The Challenges of Mainstreaming WIL. Paper presented at the ALTC NAGCAS National Symposium, Melbourne, Australia.

Merriam, S. B. (1998). Qualitative Research and Case Study Applications in Education. San Francisco: Jossey Bass.

Muldoon, R. (2009). Graduate Attributes and Extra-curricular Activity. WIL Vignettes Retrieved May 11, 2011, from http://www.acen.edu.au/vignettes/Graduate-Attributes-and-Extra-curricularActivity.php

Newell, F. (2009). Learning in the Workplace and Community Certificate II in Hospitality (Kitchen Operations) School Canteen Program. WIL Vignettes Retrieved May 11, 2011, from http://www.acen.edu.au/vignettes/Learning-in-the-Workplace-and-Community-CertificateII-in-Hospitality-(Kitchen-Operations)-School-Canteen-Program.php

Patrick, C., Peach, D., Pocknee, C., Webb, F., Fletcher, M., \& Pretto, G. (2009). The WIL Report: Work Integrated Learning-A National Scoping Study. Brisbane, Australia: Australian Learning and Teaching Council (ALTC).

Pomeranz, K. (2008). Multidisciplinary Industry Based Learning. WIL Vignettes Retrieved May 10, 2011, from http://www.altcexchange.edu.au/system/files/Multidisciplinary_Industry_ Based_Learning_SU.pdf

Rowland, S. (2002). Overcoming Fragmentation in Professional Life: The Challenge for Academic Development. Higher Education Quarterly, 56(1), 52-64

Sandringham Publishing. (2009). What is the Humanities? Transworld Education Retrieved May 11, 2011, from http://www.transworldeducation.com/artshuman.htm

Shirley, M., Davies, I., \& Cockburn, T. (2008). Virtual Placement Project (VPP). WIL Vignettes Retrieved May 11, 2011, from http://www.acen.edu.au/vignettes/Law---Virtual-placement.php

Stake, R. (2005). Qualitative Case Studies. In N. Denzin \& Y. Lincoln (Eds.), The Sage Handbook of Qualitative Research ( $3^{\text {rd }}$ ed.). London: Sage Publications.

Weathered, L. (2009). Innocence Project. WIL Vignettes Retrieved May 11, 2011, from http://www.acen.edu.au/vignettes/Innocence-Project.php

Whitehead, J., \& McNiff, J. (2006). Action Research Living Theory. London: Sage Publications.

Yin, R. K. (2003). Case Study Research: Design and Methods ( $3^{\text {rd }}$ ed.). Thousand Oaks: Sage Publications. 


\section{About the Authors}

Catherine Pocknee

Cathy is an Academic Development Advisor in the Swinburne Professional Learning Unit at Swinburne University of Technology in Melbourne, Australia where she supports the Faculty of Life and Social Science in the enhancement of Learning and Teaching practice. She has a strong background in educational research, particularly educational technology and is currently undertaking a $\mathrm{PhD}$ investigating ideas of strategic educational change and leadership in learning and teaching practice in higher education. Cathy has been an active participant and researcher in a number of educational research projects and recently comanaged the national Australian Learning and Teaching Council (ALTC) Discipline-Based Initiatives Project Work Integrated Learning: A national framework for future progress, which undertook the first large scale scoping study of Work Integrated Learning (WIL) curriculum in contemporary Australian higher education in order to improve the learning experience of students.

\section{Gabriella Pretto}

Gabriella has taught in secondary schools, TAFE and Higher Education for many years. Her qualifications are in Information Technology and Humanities. In recent years, her focus has been in educational research and working on a range of projects that include Work Integrated Learning, Academic Language and Learning in Science, and pedagogic practice in IT. She is currently completing a $\mathrm{PhD}$. 